\author{
(online) $=$ ISSN $2285-3642$ \\ ISSN-L = $2285-3642$ \\ Journal of Economic Development, Environment and People \\ Volume 9 , Issue 3, 2020 \\ URL: http://jedep.spiruharet.ro \\ e-mail: office jedep@spiruharet.ro
}

\title{
Evaluation of Financial Performances of SME's Listed in the Bist Sme Industrial Index by Using TOPSIS Multicriteria Decision Making Method ${ }^{1}$
}

\author{
Selcuk Kendirli ${ }^{2 \boxminus}$, Muhammet Selcuk Kaya ${ }^{3}$ and Mustafa Bilgin ${ }^{4}$ \\ ${ }^{2}$ Hitit University, FEAS Department of Finance and Banking \\ ${ }^{3}$ Hitit University, FEAS Department of Finance and Banking) \\ ${ }^{4}$ Hitit University, FEAS Department of Finance and Banking
}

\begin{abstract}
In this study, the financial performances of SMEs listed in the BIST SME Industrial Index are evaluated by using TOPSIS multicriteria decision-making method. The data of the study acquired from annual financial statements that were reported between the 2016-2018 period. Financial performance ranks of SMEs are determined for each year and thus comparative financial performances of SMEs are detected.

BIST SME Industrial Index is an index that includes stocks of industrial SMEs traded in BIST Stars, BIST Main, and BIST Emerging Companies markets. SMEs have great importance for the Turkish economy, with their dynamizing roles and with their crucial roles in the regional development and job creation. According to the Turkey Statistical Institute data, Turkish SMEs constitute $99.8 \%$ of all enterprises in Turkey. At the same time, Turkish SMEs provide $72.7 \%$ of total employment, $62 \%$ of total sales, and $58 \%$ of total investments in the Turkish Economy.

The Technique for Order Preference by Similarity to Ideal Solution (TOPSIS) is one of the multicriteria decision-making methods that is commonly used in the evaluation of financial performances of firms. The TOPSIS method is based on two main points: the positive ideal solution and the negative ideal solution. With the help of the TOPSIS method, the distances positive ideal solutions and negative ideal solutions of all options are calculated. Options are ranked according to their proximity to the positive ideal solution and their distance to the negative ideal solution.
\end{abstract}

Keywords: SME, Financial Performance, TOPSIS, Multicriteria Decision Making, BIST SME Industrial Index.

JEL Codes: D53, G15, G17, O16

How to cite: Kendirli, S., Kaya, M. S., Bilgin M. - Evaluation of Financial Performances of SME's Listed in the Bist Sme Industrial Index by Using TOPSIS Multicriteria Decision Making Method, Journal of Economic Development, Environment and People, 9(3), p.63-74 . DOI: https://doi.org/10.26458/jedep.v9i3.671

\section{Introduction}

SMEs (Small and Medium-Sized Enterprises) are among the most important elements of economic life with their contributions to employment and their structures that can easily adapt to changes. In all national economies, more than $70 \%$ of firms are SMEs and in most countries, more than $90 \%$ of firms are SMEs

\footnotetext{
${ }^{1}$ This study is a revised and recontrolled version of the study presented at the ECONALANYA 2019 congress held on 24-25th October 2019 in Alanya, Turkey.

${ }^{+}$Corresponding author. Tel.: +00905423239238; fax: +903642257711. E-mail address:selcukkendirli@yahoo.com , selcukkendirli@hitit.edu.tr.
} 


\author{
(online) = ISSN $2285-3642$ \\ ISSN-L = $2285-3642$ \\ Journal of Economic Development, Environment and People \\ Volume 9, Issue 2, 2019 \\ URL: http://jedep.spiruharet.ro \\ e-mail: office jedep@spiruharet.ro
}

(OECD,2017). As awareness of the importance of SMEs in the economy increases, governments and international organizations are increasing their policies to support SMEs. In this context, Borsa İstanbul has decided to establish SME Industry Index and BIST SME Industry index started to be calculated as of December 2013.

Financial performance is a result-oriented type of business performance based on the use of financial indicators of the firm, reflecting the degree of fulfillment of the economic objectives of the firm (Başdar, 2019). Evaluation of the financial performance of SMEs is of great importance for the owners, investors, lenders, and other stakeholders. In this respect, multi-criteria decision-making methods that allow comparative measurement of different alternatives are among the methods used extensively in the measurement of the financial performance of firms.

TOPSIS was developed by Hwang and Yoon in 1980 and is a multi-criteria decision-making method that has been applied in many different areas from firm performance measurement to car selection. In the TOPSIS method, two values called positive ideal solution and negative ideal solution are calculated. The different alternatives are ranked according to their proximity to the positive ideal solution and their distance to the negative ideal solution (Özbek, 2017).

\title{
2. Literature Review
}

Bakırcı, Eslamian Shiraz, and Sattary (2014) have determined the financial performance of 14 companies in the Iron and Steel Industry's main industry sector between the years 2009-2011 by using TOPSIS and DEA (Data Envelopment Analysis) multi-criteria decision-making methods. They used Data Envelopment Analysis super efficiency and TOPSIS methods to determine the performance rankings of the firms that they determined their relative efficiency levels by DEA. Although they attained approximate firm financial performance rankings, the financial performance rankings they determined using TOPSIS and DEA methods are not exactly the same.

Özçelik and Kandemir (2015) have determined the financial performance of 7 tourism companies traded on BIST between 2010 and 2014 by using the financial ratios of the firms as a basis for the TOPSIS method.

Sakarya and Akkuş (2015) analyzed the financial performance of cement companies traded in BIST between the years 2010-2013 using the TOPSIS method, They analyzed firm financial performance firstly by using traditional financial ratios and then by using cash flow ratios. As a result of the study, differences are detected between the results obtained according to traditional financial ratios and the results obtained according to cash flow rates.

Akbulut and Coşkun (2015) determined the financial performances of 32 manufacturing companies traded on BIST between 2010 and 2012 by TOPSIS method and analyzed the correlation between the companies' market value/book value ratios and companies TOPSIS scores. As a result of the study, they found that there is no statistically significant relationship between the stock market performances determined by using market value/book value ratios and the financial performances determined by TOPSIS method.

Akgün and Soy Temür (2016) determined the financial performances of 2 airline companies registered in BIST transportation index between 2010 and 2015 using TOPSIS method. 


\author{
(online) = ISSN $2285-3642$ \\ ISSN-L = $2285-3642$ \\ Journal of Economic Development, Environment and People \\ Volume 9 , Issue 3, 2020 \\ URL: $\underline{\text { http://jedep.spiruharet.ro }}$ \\ e-mail: office jedep@spiruharet.ro
}

İlkuçar and Çifci (2016) evaluated financial performances of 6 electric generation companies for 2015 by using TOPSIS method.

Aytekin and Karamaşa (2017) analyzed financial performances of 6 insurance companies traded in BIST by using 6 financial indicators from 2011 to 2015. They obtained financial performances rankings of 6 insurance firms by using the fuzzy (Shannon's entropy-based) TOPSIS method.

Balcı (2017) examined the financial performances of 27 public hospitals between 2014 and 2015 by using TOPSIS method. As a result of the study, significant differences were observed among the financial performances of public hospitals by year.

Metin, Yaman, and Korkmaz (2017) determined the financial performance of 11 energy companies traded in BIST between 2010 and 2015 by using TOPSIS and MOORA methods and compared the performance rankings obtained in both methods.

Orçun and Eren (2017) financial performance of technology companies traded on BIST between 2010 and 2015 analyzed by using TOPSIS method. Also, financial performance rankings and stock exchange return rankings of the companies for the relevant periods were analyzed and no significant relationship could be determined.

Kayalı and Aktaş (2018) examined the financial performances of firms in the automotive sector traded on BIST between 2010 and 2015 using TOPSIS method. As a result of the study, they were determined that some companies have maintained their place in financial performance rankings and some companies have changed their place in the rankings year to year.

Özçelik and Küçükçakal (2019) analyzed the financial performance of financial leasing and factoring companies traded in BIST between 2009 and 2016 by TOPSIS method. They used the liquidity, activity, and profitability ratios of the companies as criteria in TOPSIS method.

\title{
3. Data and Methodology
}

Financial ratios of 42 firms listed in the BIST SME Industrial Index between 2016-2018 years are used as decision criteria of TOPSIS analysis. Three main financial ratio groups are selected as decision criteria; liquidity ratios, turnover ratios, and profitability ratios. Annual financial reports of 42 firms are obtained from the website of the Public Disclosure Platform (kap.gov.tr) and financial ratios are calculated for each firm and year. The financial ratios used in this study were selected through a literature review. The list of financial ratios are shown in table 1 :

Table. 1. Selected Financial Ratios

\begin{tabular}{|c|l|c|l|}
\hline $\begin{array}{c}\text { Group of } \\
\text { Financial Ratios }\end{array}$ & Selected Ratio & Calculation Formula of The Selected Ratio & Abbreviation \\
\hline Liquidity Ratios & Current Ratio & Current Assets/Current Liabilities & CuR \\
\cline { 2 - 4 } & Acid-Test Ratio & Current Assets-Inventories / Current Liabilities & AcTR \\
\cline { 2 - 4 } & Cash Ratio & Cash+ Marketable Securities / Current Liabilities & CaR \\
\hline Turnover Ratios & $\begin{array}{l}\text { Accounts Receivable } \\
\text { Turnover Ratio }\end{array}$ & Net Sales / Average Accounts Receivable & ARTR \\
\hline
\end{tabular}




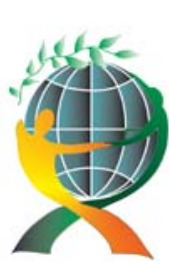

\author{
(online) $=$ ISSN $2285-3642$ \\ ISSN-L = $2285-3642$ \\ Journal of Economic Development, Environment and People \\ Volume 9, Issue 2, 2019
}

URL: http://jedep.spiruharet.ro

e-mail: office jedep@spiruharet.ro

\begin{tabular}{|c|c|c|c|}
\hline & $\begin{array}{l}\text { Inventory Turnover } \\
\text { Ratio }\end{array}$ & Cost of Good Sold/Average Inventory & ITR \\
\hline & $\begin{array}{l}\text { Total Asset Turnover } \\
\text { Ratio }\end{array}$ & Net Sales / Total Assets & TATR \\
\hline \multirow{3}{*}{$\begin{array}{l}\text { Profitability } \\
\text { Ratios }\end{array}$} & Net Profit Margin & Net Income / Sales & NPM \\
\hline & Return on Equity & Net Income / Average Shareholder's Equity & ROE \\
\hline & Operating Profit Margin & Operating Earnings / Revenue & OPM \\
\hline
\end{tabular}

Liquidity ratios are the ratios that reveal the ability of a firm to pay its current assets and overdue (short-term) debts. Turnover rates are the ratios that show how firms use effectively their assets. Profitability ratios indicate the effectiveness of the firm in terms of profit-making in the operating period(Okka, 2009).

With TOPSIS method, alternatives are sorted according to certain criteria. The TOPSIS method has 6 steps (Özdemir, 2015; Özbek,2017):

Step 1 is the formation of the decision matrix. The decision matrix is a matrix of decision criteria and factors. It can be shown as follows:

$$
A_{i j}=\left[\begin{array}{cccc}
a_{11} & a_{12} & \ldots & a_{1 n} \\
a_{21} & a_{22} & \ldots & a_{2 n} \\
\cdot & & & \cdot \\
\cdot & & & \cdot \\
\cdot & & & \cdot \\
a_{m 1} & a_{m 2} & \ldots & a_{m n}
\end{array}\right]
$$

Step 2 is the creation of a normalized matrix. After squaring each aij value in the decision matrix, the square root of the sum of squares is taken for each criterion. After taking the square root of the sum of the squares of the data based on criteria, each data is divided by the square root of the sum of the squares of the data of the criteria to which it belongs, and the normalization matrix is completed.

$$
r_{i j}=\frac{a_{i j}}{\sqrt{\sum_{k=1}^{m} a_{i j}^{2}}}
$$

Step 3 is the creation of a weighted decision matrix. The weights of the evaluation criteria $\left({ }^{w_{i}}\right)$ are determined. The sum of all weights must be equal to 1 . The weighted decision matrix is generated by multiplying the data of the criteria by the weights of the criteria. 


\author{
(online) $=$ ISSN $2285-3642$ \\ ISSN-L = $2285-3642$ \\ Journal of Economic Development, Environment and People \\ Volume 9 , Issue 3, 2020 \\ URL: http://jedep.spiruharet.ro \\ e-mail: office jedep@spiruharet.ro
}

$$
V_{i j}=\left[\begin{array}{cccc}
w_{1} r_{11} & w_{2} r_{12} & \ldots & w_{n} r_{1 n} \\
w_{1} r_{21} & w_{2} r_{22} & \ldots & w_{n} r_{2 n} \\
\cdot & & & \cdot \\
\cdot & & & \cdot \\
\cdot & & & \cdot \\
w_{1} r_{m 1} & w_{2} r_{m 2} & \ldots & w_{n} r_{m n}
\end{array}\right]
$$

Step 4 is to obtain ideal and negative ideal solution values. After obtaining the weighted decision matrix, maximum values of positive criteria, and minimum values of negative criteria are determined and ideal solution values are found. Negative ideal solution values are obtained by determining minimum values of positive criteria and maximum values of negative criteria. Ideal and Negative Ideal solutions are expressed in the following formulas:

$$
A^{*}=\left\{\left(\max _{i} v_{i j} \mid j \in J\right),\left(\min _{i} v_{i j} \mid j \in J^{\prime}\right\} \quad A^{-}=\left\{\left(\min _{i} v_{i j} \mid j \in J\right),\left(\max _{i} v_{i j} \mid j \in J^{\prime}\right\}\right.\right.
$$

Step 5 is to obtain the distance from ideal and negative ideal points. In the TOPSIS method, the Euclidean distance is used to calculate the distance to ideal and non-ideal points. Euclidean distance is calculated by the following formulas:

$$
S_{i}^{*}=\sqrt{\sum_{j=1}^{n}\left(v_{i j}-v_{j}^{*}\right)^{2}} \quad S_{i}^{-}=\sqrt{\sum_{j=1}^{n}\left(v_{i j}-v_{j}^{-}\right)^{2}}
$$

Step 6 is the calculation of the proximity to the ideal solution. The ideal and negative ideal discrimination measures are used to calculate the proximity of each decision point to the ideal solution. and shows the absolute closeness of the respective decision point to the ideal solution, and the absolute proximity of the relevant decision point to the negative ideal solution. The relative proximity to the ideal solution is calculated by the following formula:

$$
C_{i}^{*}=\frac{S_{i}^{-}}{S_{i}^{-}+S_{i}^{*}}
$$

\title{
4. Results and Discussion
}

Firstly, the selected financial ratios of 42 firms included in the BIST SME industry index between 20162018 were calculated. As an example of the calculated financial ratios, the financial ratios for 2018 are given in table 2 . 


\author{
(online) $=$ ISSN $2285-3642$ \\ ISSN-L = $2285-3642$ \\ Journal of Economic Development, Environment and People \\ Volume 9, Issue 2, 2019 \\ URL: http://jedep.spiruharet.ro \\ e-mail: office jedep@spiruharet.ro
}

Table. 2. Financial Ratios for 2018 of 42 SME Listed in BIST SME Industry Index

\begin{tabular}{|c|c|c|c|c|c|c|c|c|c|c|c|}
\hline CuR & 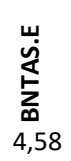 & 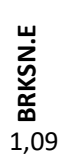 & 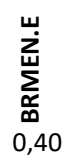 & 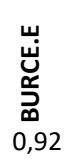 & 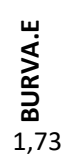 & 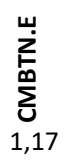 & 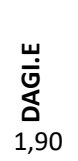 & 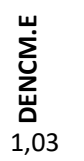 & $\begin{array}{l}\text { ب } \\
\stackrel{\underline{\underline{x}}}{\bar{\Delta}} \\
0,46\end{array}$ & 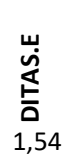 & 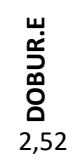 \\
\hline AcTR & 3,11 & 0,80 & 0,40 & 0,47 & 1,00 & 1,13 & 1,01 & 0,64 & 0,14 & 0,89 & 2,43 \\
\hline CaR & 1,32 & 0,15 & 0,37 & 0,04 & 0,16 & 0,14 & 0,26 & 0,00 & 0,03 & 0,08 & 1,16 \\
\hline ARTR & 3,23 & 6,28 & 19,90 & 1,42 & 2,81 & 87,43 & 1,70 & 4,52 & 3,07 & 3,85 & 30,03 \\
\hline ITR & 3,09 & 4,55 & 0,89 & 2,54 & 5,66 & 3,77 & 4,36 & 3,30 & 18,66 & 4,74 & 3,91 \\
\hline TATR & 0,40 & 1,20 & 0,02 & 0,30 & 1,21 & 2,16 & 0,77 & 0,86 & 0,23 & 1,38 & 1,66 \\
\hline NPM & 0,13 & 0,01 & $-4,23$ & $-0,07$ & 0,00 & 0,04 & $-0,06$ & 0,00 & $-1,23$ & 0,07 & 0,03 \\
\hline ROE & 0,07 & 0,02 & $-0,22$ & $-0,05$ & 0,02 & 0,20 & $-0,08$ & $-0,01$ & $-0,86$ & 0,26 & 0,10 \\
\hline OPM & 0,14 & 0,05 & $-0,02$ & 0,04 & 0,12 & $-0,03$ & 0,08 & 0,05 & $-0,88$ & 0,15 & 0,04 \\
\hline
\end{tabular}

\begin{tabular}{|c|c|c|c|c|c|c|c|c|c|c|c|}
\hline & 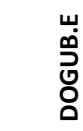 & بت & 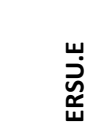 & 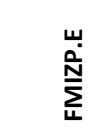 & 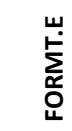 & 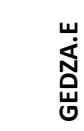 & 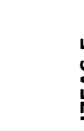 & 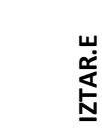 & بُ & 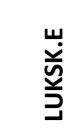 & L \\
\hline CuR & 0,32 & 1,26 & 4,41 & 5,50 & 1,06 & 4,86 & 2,21 & 0,63 & 2,56 & 1,61 & 1,52 \\
\hline ActR & 0,10 & 0,70 & 1,59 & 5,09 & 0,96 & 3,84 & 1,27 & 0,49 & 2,18 & 0,91 & 1,27 \\
\hline CaR & 0,01 & 0,05 & 0,01 & 0,06 & 0,07 & 1,67 & 0,42 & 0,04 & 0,14 & 0,08 & 0,35 \\
\hline ARTR & 1,83 & 1,41 & 0,78 & 18,62 & 5,61 & 6,13 & 1,10 & 7,20 & 9,94 & 1,61 & 2,36 \\
\hline ITR & 5,24 & 3,17 & 9,58 & 9,05 & 1,22 & 4,68 & 1,72 & 10,12 & 2,99 & 2,53 & 1,04 \\
\hline TATR & 0,20 & 0,47 & 0,17 & 1,30 & 0,63 & 0,84 & 0,56 & 0,41 & 1,13 & 0,21 & 0,41 \\
\hline NPM & $-0,51$ & 0,04 & 0,01 & 0,27 & 0,09 & 0,17 & 0,03 & $-0,01$ & 0,03 & 0,50 & $-0,17$ \\
\hline ROE & $-0,25$ & 0,05 & 0,00 & 0,42 & 0,37 & 0,18 & 0,03 & $-0,01$ & 0,05 & 0,18 & $-0,15$ \\
\hline OPM & $-0,38$ & 0,04 & 0,00 & 0,27 & 0,22 & 0,26 & 0,07 & 0,04 & 0,04 & $-0,03$ & 0,23 \\
\hline
\end{tabular}

\begin{tabular}{|c|c|c|c|c|c|c|c|c|c|c|c|}
\hline & $\begin{array}{l}\text { بپ } \\
\text { 㐫 } \\
\stackrel{\text { }}{\Sigma}\end{array}$ & 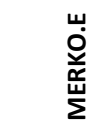 & 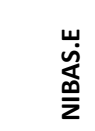 & بّ & 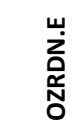 & $\begin{array}{l}\text { بّ } \\
\text { 뭄 }\end{array}$ & 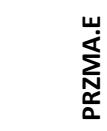 & 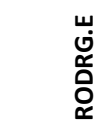 & 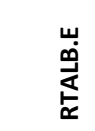 & 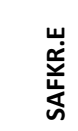 & بـ \\
\hline CuR & 9,73 & 1,13 & 0,78 & 0,66 & 1,52 & 3,71 & 5,09 & 1,59 & 3,79 & 2,03 & 1,33 \\
\hline AcTR & 8,22 & 0,33 & 0,64 & 0,54 & 0,85 & 3,04 & 2,98 & 0,83 & 3,35 & 1,38 & 0,12 \\
\hline CaR & 0,58 & 0,01 & 0,11 & 0,01 & 0,06 & 0,56 & 0,08 & 0,20 & 0,71 & 0,28 & 0,00 \\
\hline ARTR & 4,52 & 1,28 & 7,90 & 11,29 & 3,14 & 3,27 & 0,95 & 1,08 & 4,54 & 3,65 & 1,39 \\
\hline ITR & 5,79 & 6,26 & 4,85 & 2,83 & 4,79 & 1,53 & 0,92 & 2,72 & 2,45 & 3,45 & 23,92 \\
\hline TATR & 0,86 & 0,77 & 0,46 & 0,63 & 1,09 & 0,64 & 0,21 & 0,65 & 0,31 & 1,02 & 1,01 \\
\hline NPM & 0,02 & $-0,08$ & $-0,12$ & $-0,04$ & 0,10 & 0,08 & 0,04 & 0,07 & $-0,02$ & 0,14 & 0,00 \\
\hline ROE & 0,02 & $-0,22$ & $-0,09$ & $-0,06$ & 0,23 & 0,06 & 0,01 & 0,11 & $-0,01$ & 0,22 & $-0,02$ \\
\hline OPM & 0,06 & $-0,02$ & $-0,03$ & $-0,05$ & 0,15 & 0,10 & 0,09 & 0,02 & $-0,59$ & 0,04 & 0,09 \\
\hline
\end{tabular}




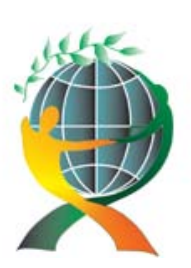

\author{
(online) $=$ ISSN $2285-3642$ \\ ISSN-L = 2285 - 3642 \\ Journal of Economic Development, Environment and People \\ Volume 9 , Issue 3, 2020
}

URL: http://jedep.spiruharet.ro

e-mail: office jedep@spiruharet.ro

\begin{tabular}{|c|c|c|c|c|c|c|c|c|c|}
\hline & ب & 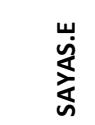 & 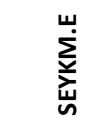 & 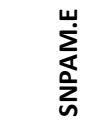 & 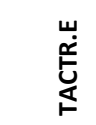 & 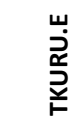 & 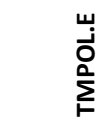 & 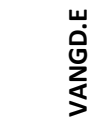 & 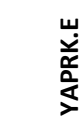 \\
\hline CuR & 0,88 & 1,34 & 5,69 & 2,29 & 0,29 & 1,47 & 1,07 & 5,34 & 1,08 \\
\hline AcTR & 0,59 & 0,74 & 3,64 & 1,71 & 0,24 & 0,81 & 0,87 & 5,15 & 0,76 \\
\hline CaR & 0,01 & 0,05 & 0,31 & 0,47 & 0,00 & 0,27 & 0,03 & 0,18 & 0,07 \\
\hline ARTR & 5,15 & 2,12 & 3,25 & 3,62 & 6,24 & 1,80 & 6,23 & 4,15 & 6,25 \\
\hline ITR & 3,70 & 8,91 & 4,67 & 3,44 & 7,17 & 4,15 & 1,71 & 27,19 & 10,47 \\
\hline TATR & 1,09 & 0,72 & 0,91 & 0,36 & 0,15 & 0,65 & 0,87 & 0,07 & 0,59 \\
\hline NPM & 0,01 & $-0,43$ & 0,11 & 0,16 & $-0,45$ & $-0,32$ & $-0,02$ & 0,15 & 0,11 \\
\hline ROE & 0,05 & $-0,91$ & 0,12 & 0,09 & $-0,16$ & $-1,33$ & $-0,05$ & 0,01 & 0,10 \\
\hline OPM & 0,10 & 0,03 & 0,13 & 0,31 & $-0,37$ & $-0,31$ & 0,10 & $-0,38$ & 0,30 \\
\hline
\end{tabular}

Selected financial ratios are used as a decision matrix. In step 2, the normalized matrix is formed by dividing each of the proportions in the decision matrix by the square root of the sum of the squares of the proportions. The weighted normalized matrix was obtained by weighting the normalized matrix. Equal weight was given to each decision criterion (financial ratio) while the weighting process was made and the weight given to each ratio was $1 / 9$. After weighting, the maximum and minimum values for each decision criterion (financial ratio) were determined as ideal solution points and negative ideal solution points.

After obtaining the ideal and negative ideal solution points, the distance to ideal and non-ideal points was obtained by using $\mathrm{S}_{\mathrm{i}}^{*}=\sqrt{\sum_{\mathrm{j}=1}^{\mathrm{n}}\left(\mathrm{v}_{\mathrm{ij}}-\mathrm{v}_{\mathrm{j}}^{*}\right)^{2}}$ and $\mathrm{S}_{\mathrm{i}}^{-} \underset{\mathrm{S}_{\mathrm{i}}^{-}}{=} \sqrt{\sum_{\mathrm{j}=1}^{\mathrm{n}}\left(\mathrm{v}_{\mathrm{ij}}-\mathrm{v}_{\mathrm{j}}^{-}\right)^{2}}$ formulas. Finally, the proximity to the ideal solution $W$ was calculated by using $C_{i}^{*}=\frac{S_{i}^{-}}{S_{i}^{-}+S_{i}^{*}}$ formula.

Table. 3. BIST SME Industry Index Year 2016 TOPSIS Ranking

\begin{tabular}{|l|l|l|l|}
\hline \multicolumn{4}{|c|}{ BIST SME Industry Index Year 2016 TOPSIS Ranking } \\
\hline Rank & Company Name & TOPSIS Score & \multicolumn{1}{c|}{ Sector } \\
\hline $\mathbf{1}$ & Sönmez Cotton & 0,607 & Textile, Clothing, Leather \\
\hline $\mathbf{2}$ & Federal-Mogul İzmit Piston and Pin & 0,571 & Metal Goods, Machinery and Equipment Making \\
\hline $\mathbf{3}$ & Gediz Packaging & 0,542 & Chemical, Petroleum Rubber, Plastic \\
\hline $\mathbf{4}$ & Çimbeton Cement & 0,514 & Stone Soil Based \\
\hline $\mathbf{5}$ & Politeknik Metal & 0,508 & Chemical, Petroleum Rubber, Plastic \\
\hline $\mathbf{6}$ & Mega Polyethylene Foam & 0,505 & Chemical, Petroleum Rubber, Plastic \\
\hline $\mathbf{7}$ & RTA Laboratories & 0,481 & Chemical, Petroleum Rubber, Plastic \\
\hline $\mathbf{8}$ & Seyitler Chemistry & 0,478 & Chemical, Petroleum Rubber, Plastic \\
\hline $\mathbf{9}$ & Doğan Burda Magazine & 0,473 & Paper and Paper Products Printing \\
\hline $\mathbf{1 0}$ & Bandırma Packaging Materials & 0,461 & Metal Goods, Machinery and Equipment Making \\
\hline $\mathbf{1 1}$ & Formet Steel Door & 0,460 & Metal Goods, Machinery and Equipment Making \\
\hline $\mathbf{1 2}$ & Lüks Velvet & 0,455 & Textile, Clothing, Leather \\
\hline $\mathbf{1 3}$ & Yaprak Farm & 0,455 & Agriculture, Forestry and Fisheries \\
\hline $\mathbf{1 4}$ & Özerden Plastic Products & 0,442 & Chemical, Petroleum Rubber, Plastic \\
\hline $\mathbf{1 5}$ & Prizma Press Typography & 0,441 & Paper and Paper Products Printing \\
\hline $\mathbf{1 6}$ & Safkar Ege Cooling & 0,437 & Metal Goods, Machinery and Equipment Making \\
\hline
\end{tabular}


(online) = ISSN $2285-3642$

ISSN-L = $2285-3642$

Journal of Economic Development, Environment and People

Volume 9, Issue 2, 2019

URL: http://jedep.spiruharet.ro

e-mail: office jedep@spiruharet.ro

\begin{tabular}{|c|c|c|c|}
\hline 17 & Kristal Cola Beverages & 0,430 & Food, Beverages \& Tobacco \\
\hline 18 & Taze Dry Food & 0,415 & $\begin{array}{l}\text { Manufacturing Industry / Food, Beverages \& } \\
\text { Tobacco }\end{array}$ \\
\hline 19 & İzmir Brush & 0,412 & Chemical, Petroleum Rubber, Plastic \\
\hline 20 & Ersu Fruit and Food & 0,411 & Food, Beverages \& Tobacco \\
\hline 21 & Saray Printing & 0,411 & Metal Goods, Machinery and Equipment Making \\
\hline 22 & Berkosan & 0,409 & Chemical, Petroleum Rubber, Plastic \\
\hline 23 & Dagi Clothing & 0,405 & Textile, Clothing, Leather \\
\hline 24 & Iz Livestock and Food & 0,403 & Agriculture, Forestry and Fisheries \\
\hline 25 & Te-mapol Polymer Plastic & 0,399 & Chemical, Petroleum Rubber, Plastic \\
\hline 26 & Rodrigo Textile & 0,398 & Textile, Clothing, Leather \\
\hline 27 & Say Advertising Building Decoration & 0,396 & Metal Goods, Machinery and Equipment Making \\
\hline 28 & Burçelik Valve & 0,388 & Metal Main Industry \\
\hline 29 & Burçelik Stell Casting & 0,388 & Metal Main Industry \\
\hline 30 & $\begin{array}{l}\text { Ditaş Doğan Spare Parts } \\
\text { Manufacturing }\end{array}$ & 0,381 & Metal Goods, Machinery and Equipment Making \\
\hline 31 & Makine Tool Industry & 0,379 & Metal Goods, Machinery and Equipment Making \\
\hline 32 & Oylum Industrial Investments & 0,373 & Food, Beverages \& Tobacco \\
\hline 33 & Niğde Concrete & 0,363 & Stone Soil Based \\
\hline 34 & Merko Food Industry Trade & 0,348 & Food, Beverages \& Tobacco \\
\hline 35 & Denizli Glass Industry & 0,333 & Stone Soil Based \\
\hline 36 & Doğusan & 0,273 & Stone Soil Based \\
\hline 37 & Birlik Textile & 0,260 & Textile, Clothing, Leather \\
\hline 38 & Taç Agricultural Products & 0,244 & Agriculture, Forestry and Fisheries \\
\hline 39 & Diriliş Textile & 0,162 & Textile, Clothing, Leather \\
\hline 40 & Vanet Food Industry & 0,147 & Food, Beverages \& Tobacco \\
\hline 41 & Emek Electrical Industry & 0,001 & Metal Goods, Machinery and Equipment Making \\
\hline 42 & Sanifoam Sponge & 0,001 & Chemical, Petroleum Rubber, Plastic \\
\hline
\end{tabular}

According to the results in Table 3, the top five companies with the highest financial performances in 2016 are; Sönmez Cotton, Federal-Mogul İzmit Piston, and Pin, Gediz Packaging, Çimbeton Cement, and Polytechnic Metal. Additionally, Taç Agricultural Products, Diriliş Textile, Vanet Food Industry, Emek Electrical Industry, and Sanifoam Sponge, are then ranked at the bottom of the 2016 financial performance ranking with the lowest financial performances.

Table. 4. BIST SME Industry Index Year 2017 TOPSIS Ranking and Changes

in Ranking Compared to Last Year's Ranking

\begin{tabular}{|c|c|c|c|c|}
\hline \multicolumn{5}{|c|}{ BIST SME Industry Index Year 2017 TOPSIS Ranking } \\
\hline Rank & Company Name & $\begin{array}{c}\text { TOPSIS } \\
\text { Score }\end{array}$ & Sector & $\begin{array}{l}\text { Difference } \\
\text { in Ranking }\end{array}$ \\
\hline 1 & Federal-Mogul İzmit Piston and Pin & 0,768 & $\begin{array}{l}\text { Metal Goods, Machinery and Equipment } \\
\text { Making }\end{array}$ & +1 \\
\hline 2 & Mega Polyethylene Foam & 0,597 & Chemical, Petroleum Rubber, Plastic & +4 \\
\hline 3 & Gediz Packaging & 0,586 & Chemical, Petroleum Rubber, Plastic & 0 \\
\hline 4 & Politeknik Metal & 0,582 & Chemical, Petroleum Rubber, Plastic & +1 \\
\hline 5 & RTA Laboratories & 0,580 & Chemical, Petroleum Rubber, Plastic & +2 \\
\hline 6 & Burçelik Valve & 0,563 & Metal Main Industry & +22 \\
\hline 7 & Sönmez Textile & 0,561 & Textile, Clothing, Leather & -7 \\
\hline
\end{tabular}


(online) = ISSN $2285-3642$

ISSN-L = $2285-3642$

Journal of Economic Development, Environment and People

Volume 9 , Issue 3, 2020

URL: http://jedep.spiruharet.ro

e-mail: office jedep@spiruharet.ro

\begin{tabular}{|c|c|c|c|c|}
\hline 8 & Formet Steel Door & 0,555 & $\begin{array}{l}\text { Metal Goods, Machinery and Equipment } \\
\text { Making }\end{array}$ & +3 \\
\hline 9 & Seyitler Chemistry & 0,552 & Chemical, Petroleum Rubber, Plastic & -1 \\
\hline 10 & Çimbeton & 0,552 & Stone Soil Based & -6 \\
\hline 11 & Doğan Burda Magazine & 0,547 & Paper and Paper Products Printing & -2 \\
\hline 12 & Yaprak Farm & 0,546 & Agriculture, Forestry and Fisheries & +1 \\
\hline 13 & $\begin{array}{l}\text { Ditaş Doğan Spare Parts } \\
\text { Manufacturing }\end{array}$ & 0,531 & $\begin{array}{l}\text { Metal Goods, Machinery and Equipment } \\
\text { Making }\end{array}$ & +17 \\
\hline 14 & Saray Typography & 0,525 & $\begin{array}{l}\text { Metal Goods, Machinery and Equipment } \\
\text { Making }\end{array}$ & +7 \\
\hline 15 & Özerden Plastic & 0,524 & Chemical, Petroleum Rubber, Plastic & -1 \\
\hline 16 & Dagi Clothing & 0,523 & Textile, Clothing, Leather & +7 \\
\hline 17 & Makine Tool Industry & 0,521 & $\begin{array}{l}\text { Metal Goods, Machinery and Equipment } \\
\text { Making }\end{array}$ & +14 \\
\hline 18 & Kristal Cola & 0,520 & Food, Beverages \& Tobacco & -1 \\
\hline 19 & Berkosan & 0,519 & Chemical, Petroleum Rubber, Plastic & +3 \\
\hline 20 & Ersu Fruit and Food & 0,519 & Food, Beverages \& Tobacco & 0 \\
\hline 21 & Taze Dry Food & 0,519 & Food, Beverages \& Tobacco & -3 \\
\hline 22 & Taç Agricultural Products & 0,513 & Agriculture, Forestry and Fisheries & +16 \\
\hline 23 & Prizma Press Typography & 0,510 & Paper and Paper Products Printing & -8 \\
\hline 24 & Bandırma Packaging Materials & 0,508 & $\begin{array}{l}\text { Metal Goods, Machinery and Equipment } \\
\text { Making }\end{array}$ & -14 \\
\hline 25 & Safkar Ege Cooling & 0,503 & $\begin{array}{l}\text { Metal Goods, Machinery and Equipment } \\
\text { Making }\end{array}$ & -9 \\
\hline 26 & Say Advertising Building Decoration & 0,493 & $\begin{array}{l}\text { Metal Goods, Machinery and Equipment } \\
\text { Making }\end{array}$ & +1 \\
\hline 27 & İzmir Brush & 0,492 & Chemical, Petroleum Rubber, Plastic & -8 \\
\hline 28 & Te-mapol Polymer Plastic & 0,491 & Chemical, Petroleum Rubber, Plastic & -3 \\
\hline 29 & Lüks Velvet & 0,491 & Textile, Clothing, Leather & -17 \\
\hline 30 & Rodrigo Textile & 0,484 & Textile, Clothing, Leather & -4 \\
\hline 31 & Denizli Glass Industry & 0,477 & Stone Soil Based & -4 \\
\hline 32 & Oylum Industrial Investments & 0,476 & Food, Beverages \& Tobacco & 0 \\
\hline 33 & Burçelik Stell Casting & 0,474 & Metal Main Industry & -4 \\
\hline 34 & İz Livestock and Food & 0,473 & Agriculture, Forestry and Fisheries & -10 \\
\hline 35 & Diriliş Textile & 0,462 & Textile, Clothing, Leather & -5 \\
\hline 36 & Niğde Concrete & 0,446 & Stone Soil Based & -3 \\
\hline 37 & Birlik Textile & 0,432 & Textile, Clothing, Leather & 0 \\
\hline 38 & Doğusan & 0,391 & Stone Soil Based & -2 \\
\hline 39 & Merko Food Industry Trade & 0,350 & Food, Beverages \& Tobacco & -5 \\
\hline 40 & Vanet Food Industry & 0,285 & Food, Beverages \& Tobacco & 0 \\
\hline 41 & Sanifoam Foam & 0,001 & Chemical, Petroleum Rubber, Plastic & +1 \\
\hline 42 & Emek Electric Industry & 0,001 & $\begin{array}{l}\text { Metal Goods, Machinery and Equipment } \\
\text { Making }\end{array}$ & -1 \\
\hline
\end{tabular}

According to the results in Table 4, the top five companies with the highest financial performances in 2016 are; Federal-Mogul İzmit Piston and Pin, Mega Polyethylene Foam, Gediz Packaging, Politeknik Metal, and RTA Laboratories.

Doğusan, Merko Food Industry Trade, Vanet Food Industry, Sanifoam Foam, Emek Electric Industry are ranked at the bottom of the 2017 financial performance ranking with the lowest financial performances. 
(online) $=$ ISSN $2285-3642$

ISSN-L = $2285-3642$

Journal of Economic Development, Environment and People

Volume 9, Issue 2, 2019

URL: http://jedep.spiruharet.ro

e-mail: office jedep@spiruharet.ro

Table. 5. BIST SME Industry Index Year 2018 TOPSIS Ranking and

Changes in Ranking Compared to Last Year's Ranking

\begin{tabular}{|c|c|c|c|c|}
\hline \multicolumn{4}{|c|}{ BIST SME Industry Index Year 2018 TOPSIS Ranking } & \multirow[b]{2}{*}{$\begin{array}{l}\text { Difference } \\
\text { in Ranking }\end{array}$} \\
\hline Rank & Company Name & $\begin{array}{l}\text { TOPSIS } \\
\text { Score }\end{array}$ & Sector & \\
\hline 1 & Çimbeton & 0,621 & Stone Soil Based & +9 \\
\hline 2 & $\begin{array}{l}\text { Federal-Mogul İzmit Piston } \\
\text { and Pin }\end{array}$ & 0,613 & Metal Goods, Machinery and Equipment Making & -1 \\
\hline 3 & Gediz Packaging & 0,606 & Chemical, Petroleum Rubber, Plastic & 0 \\
\hline 4 & Doğan Burda Magazine & 0,601 & Paper and Paper Products Printing & -7 \\
\hline 5 & Mega Polietilen Foam & 0,588 & Chemical, Petroleum Rubber, Plastic & -3 \\
\hline 6 & Bandırma Packaging & 0,564 & Metal Goods, Machinery and Equipment Making & +18 \\
\hline 7 & Seyitler Chemistry & 0,551 & Chemical, Petroleum Rubber, Plastic & +2 \\
\hline 8 & Sönmez Textile & 0,536 & Textile, Clothing, Leather & -1 \\
\hline 9 & Vanet Food Industry & 0,534 & Food, Beverages \& Tobacco & +31 \\
\hline 10 & Politeknik Metal & 0,534 & Chemical, Petroleum Rubber, Plastic & -6 \\
\hline 11 & Yaprak Dairy Farm & 0,529 & Agriculture, Forestry and Fisheries & +1 \\
\hline 12 & $\begin{array}{l}\text { Ditaş Doğan Spare Part } \\
\text { Manufacturing }\end{array}$ & 0,525 & Metal Goods, Machinery and Equipment Making & +1 \\
\hline 13 & Formet Stell Door & 0,524 & Metal Goods, Machinery and Equipment Making & -5 \\
\hline 14 & Safkar Ege Cooling & 0,523 & Metal Goods, Machinery and Equipment Making & +9 \\
\hline 15 & Kristal Cola & 0,521 & Food, Beverages \& Tobacco & +3 \\
\hline 16 & Özerden Plastic & 0,520 & Chemical, Petroleum Rubber, Plastic & -1 \\
\hline 17 & Saray Typography & 0,516 & Metal Goods, Machinery and Equipment Making & -3 \\
\hline 18 & Burçelik Valve & 0,510 & Metal Main Industry & -12 \\
\hline 19 & Prizma Press Typography & 0,509 & Paper and Paper Products Printing & +4 \\
\hline 20 & Lüks Velvet & 0,504 & Textile, Clothing, Leather & +9 \\
\hline 21 & İzmir Brush & 0,504 & Chemical, Petroleum Rubber, Plastic & +6 \\
\hline 22 & Berkosan & 0,504 & Chemical, Petroleum Rubber, Plastic & -3 \\
\hline 23 & Ersu Fruit and Food & 0,501 & Food, Beverages \& Tobacco & -3 \\
\hline 24 & Rodrigo Textile & 0,497 & Textile, Clothing, Leather & +6 \\
\hline 25 & İz Livestock and Food & 0,495 & Agriculture, Forestry and Fisheries & +9 \\
\hline 26 & Dagi Clothing & 0,494 & Textile, Clothing, Leather & -10 \\
\hline 27 & Machine Tool Industry & 0,493 & Metal Goods, Machinery and Equipment Making & -10 \\
\hline 28 & Te-mapol Polymer Plastic & 0,492 & Chemical, Petroleum Rubber, Plastic & 0 \\
\hline 29 & Denizli Glass Industry & 0,489 & Stone Soil Based & +2 \\
\hline 30 & $\begin{array}{l}\text { Oylum Industrial } \\
\text { Investments }\end{array}$ & 0,480 & Food, Beverages \& Tobacco & +2 \\
\hline 31 & Niğde Concrete & 0,478 & Stone Soil Based & +5 \\
\hline 32 & RTA Laboratories & 0,476 & Chemical, Petroleum Rubber, Plastic & -27 \\
\hline 33 & Burçelik Steel Casting & 0,474 & Metal Main Industry & 0 \\
\hline 34 & Merko Food Industry & 0,467 & Food, Beverages \& Tobacco & +5 \\
\hline 35 & Taç Agricultural Products & 0,423 & Agriculture, Forestry and Fisheries & -13 \\
\hline 36 & Say Advertising. & 0,421 & Metal Goods, Machinery and Equipment Making & -10 \\
\hline 37 & Doğusan & 0,406 & Stone Soil Based & +1 \\
\hline 38 & Taze Dry Food & 0,372 & Food, Beverages \& Tobacco & -17 \\
\hline 39 & Birlik Textile & 0,328 & Textile, Clothing, Leather & -2 \\
\hline 40 & Diriliş Textile & 0,315 & Textile, Clothing, Leather & -5 \\
\hline 41 & Sanifoam Foam & 0,001 & Chemical, Petroleum Rubber, Plastic & 0 \\
\hline 42 & Emek Electric Industry & 0,001 & Metal Goods, Machinery and Equipment Making & 0 \\
\hline
\end{tabular}




\author{
(online) = ISSN $2285-3642$ \\ ISSN-L = 2285 - 3642 \\ Journal of Economic Development, Environment and People \\ Volume 9 , Issue 3, 2020 \\ URL: http://jedep.spiruharet.ro \\ e-mail: office jedep@spiruharet.ro
}

According to the results in Table 5, the top five companies with the highest financial performances in 2018 are; Çimbeton, Federal-Mogul İzmit Piston and Pin, Gediz Packaging, Doğan Burda Magazine, Mega Polietilen Foam.

Taze Dry Food, Birlik Textile, Diriliş Textile, Sanifoam Foam, and Emek Electric Industry are ranked at the bottom of the 2018 financial performance ranking with the lowest financial performances.

Federal-Mogul Izmit Piston and Pin company was ranked in the first two ranks every year between 2016-2018. Based on this information, it can be said that Federal-Mogul izmit Piston and Pin company consistently showed a high financial performance between 2016-2018.

Sanifoam Foam and Emek Electric Industry are the last two companies in all years between 2016-2018.

\title{
5. Conclusion
}

TOPSIS, which is one of the Multi-Criteria Decision Making methods, is used in the evaluation of the past performance of companies or organizations as well as many decision-making problems. In this study, financial performance rankings of 42 firms included in BIST SME Industry index were determined separately for each year between 2016-2018 by using TOPSIS method. The liquidity ratios used in financial performance measurement are the ratios that show the financial performance of the firms in terms of their ability to pay their due debts, their activity ratios to show their effective use of their assets, and their profitability ratios in terms of revealing the returns they generate as a result of their activities. Therefore, the liquidity, efficiency, and profitability of the companies were evaluated together in the financial performance measurement made with TOPSIS method. Different methods or different financial ratios may be used in subsequent studies. Also, the results can be compared with the stock market performances of the firms.

\section{References}

[1] Akbulut, R., \& Coşkun, A. (2015). A Research on Financial Performance of Manufacturing Businesses That are Traded on BIST. Journal of Accounting \& Finance.

[2] Akgün, M. ve Soy Temür, A. (2016). Evaluation of Financial Performance with TOPSIS Method of Companies Which Are Listed In Transportation Index In The Istanbul Stock Exchange. Int. Journal of Management Economics and Business, ICAFR 16 Special Issue, 173-186.

[3] Aytekin, A., \& Karamaşa, Ç. (2017). Analyzing Financial Performance Of Insurance Companies Traded In BIST via Fuzzy Shannon's Entropy Based Fuzzy TOPSIS Methodology. Alphanumeric Journal, 5(1), 71-84.

[4] Bakırcl, F., Shiraz, S. E., \& Sattary, A. (2014). Financial Performance Analysis of Iron, Steel Metal Industry Sector Companies in The Borsa Istanbul: DEA Super Efficiency and TOPSIS Methods. Ege Akademik Bakis, 14(1), 9.

[5] Balcı, N. (2017). Financial Performance Analysis With TOPSIS Technique: A Case Study Of Public University Hospitals in Turkey. Yönetim ve Ekonomi Araştırmaları Dergisi, 15(Özel Sayı 1), 155-176.

[6] Başdar, C. (2019). Financial Performance Multicriteria Decision Making Methods. Bursa: Ekin Publishing, 11.

[7] illkuçar, M., \& Çifci, A. (2016). Performance evaluation of electricity generation companies traded on BIST 


\author{
(online) = ISSN $2285-3642$ \\ ISSN-L = 2285 - 3642 \\ Journal of Economic Development, Environment and People \\ Volume 9, Issue 2, 2019 \\ URL: http://jedep.spiruharet.ro \\ e-mail: office jedep@spiruharet.ro
}

according to the financial parameters through the application of TOPSIS method. International Journal of Social Sciences and Education Research, 2(3), 1010-1021.

[8] Kayalı,C., A. \& Aktas, i. (2018) Performance Evaluation and Analysis through the TOPSIS Method of Firms in the Automotive Sector Trading in BIST. Karabuk University Journal of Social Sciences Institute. 8(1), 44-59.

[9] Metin, S., Yaman, S., \& Korkmaz, T. (2017). Determination of Financial Performance by TOPSIS and MOORA Methods: A Comparative Application on BIST Energy Firms. Kahramanmaras Sutcu Imam University Journal of Social Sciences, 14 (2), 371-394.

[10] OECD. (2017). Enhancing the Contributions of SMEs in a Global and Digitalised Economy.

[11] Okka, O. (2009). Analytical Financial Management Theory and Problems. Ankara: Nobel Publishing, p $104-114$.

[12] Orçun, Ç., \& Eren, B. S. (2017). Financial Performance Evaluation with TOPSIS Method: An Application on XUTEK. Journal of Accounting \& Finance, (75).

[13] Özbek, A. (2017) Multicriteria Decision Making Methods and Problem Solutions with Excel Concept Theory Application. Ankara: Seçkin Publishing, p. 202-203.

[14] Özçelik, H., \& Kandemir, B. (2015). The Evaulation of the Financial Performances of the Tourism Enterprises Traded on BIST with TOPSIS Method. Balikesir University Journal of Social Sciences Institute, 18(33).

[15] Özçelik, H., \& Küçükçakal, Z. (2019). Analysis of Financial Performance of Financial Leasing and Factoring Companies Traded on BIST by TOPSIS Method. Journal of Accounting and Finance, (81).

[16] Özdemir, M. (2015). Multi Criteria Decision Making Methods for Solving Operational, Managerial and Strategic Problems for Operators, Engineers and Managers. B. F. Yıldırım and E. Önder (Ed.). TOPSIS (135). Bursa: Dora Publishing House.

[17] Sakarya, Ş., \& Akkuş, H. T. (2015). Comperative Analysis of Traditional Ratios with Cash Flow Ratios on Measuring Financial Performance: A Practice on BIST Cement Companies With TOPSIS Method. Afyon Kocatepe University Economics and Administrative Sciences Journal, 17(1), 109-123. 